\title{
Developing a Model of Educators' Professional Training Special for Remote Areas through the Implementation of Lesson Study
}

\author{
Nur Fauziyah $^{1} \&$ Sri Uchtiawati $^{1}$ \\ ${ }^{1}$ Mathematics Education Department, University of Muhammadiyah, Gresik, Indonesia \\ Correspondence: Nur Fauziyah, Mathematics Education Department, University of Muhammadiyah Gresik, Jl. \\ Sumatera 101 GKB Randuagung, Gresik, Indonesia. Tel: 62-813-2741-8413. E-mail:nur_fauzia@yahoo.co.id
}

Received: March 22, 2016

doi:10.5539/ies.v10n8p108
Accepted: March 7, 2017 Online Published: July 29, 2017

URL: https://doi.org/10.5539/ies.v10n8p108

\begin{abstract}
This study is an R \& D (Research and Development) project which has the main goal to develop appropriate model of professional training for remote areas in Indonesia. This research is important because there are still many teachers who teach subjects that are not in accordance with their educational background. These issues will not only adversely affect the quality of the graduates but also will be obstacles in the implementation of the programs promoted by the government. Thus, we need a model of teachers' professional training special for Remote Island by paying attention to geographical location, culture and any shortcomings of both human resources and infrastructure owned by schools. Based on the theory of training model, the need analysis, and stakeholders' inputs what can be applied is implementing an integrated thematic-based lesson study. This finding of educators' professional training model special for remote areas will help Government carry out educators' professional training in other remote regions across Indonesia.
\end{abstract}

Keywords: lesson study, Remote Island, training model

\section{Introduction}

\subsection{Background}

Bawean Island is a remote place located in Java Sea, approximately $150 \mathrm{~km}$ north of the Java Island. Administratively, this island is included in Gresik regency, East Java Province. Bawean Island consists of two regencies, namely Sangkapura and Tambak sub-districts. Its population is about 70,000 people, with the livelihood as fishermen, farmers and most of them work as migrant workers in Malaysia and Singapore. The Ethnics of population majority are Baweanese, Javanese, Madurese, Bugis and Mandailing ethnics.

Based on the data from the Education Department of Gresik regency 2014, in Bawean Island there are 18 elementary schools, 10 Junior high schools and 4 Senior high schools, both public and private. While the number of elementary school teachers is 123 people, 150 teachers for junior high schools, 83 teachers for senior high schools. Geographical location and transportation condition that connects Bawean Island to the town of Gresik regency are the major obstacles for teachers in Bawean Island to follow the progress of science and technology which cause the low quality of learning process carried out by teachers. Based on the experience of the author who did community service program (A program of Special Service Education in Remote Areas, a grant of Higher Education in 2009), when training was implemented for high school teachers in Sangkapura sub-district in Bawean Island, it was shown clearly that their pedagogic and professional competences were still low.

\subsection{Significance of the Research}

Based on the above background, the author is eager to find a model of professional training for teachers in that remote island by paying attention to geographical location, culture and any shortcomings of both human resources and infrastructure owned by each school. By finding of educators' professional training model in remote area, this model will later be used by the Government (Kemendikbud) to carry out professional training for educators in other remote regions across Indonesia. Based on the theory, a model of teachers' professional training that can be applied is Lesson Study. Lesson study is a model of educators' professional training through sustainable and collaborative learning assessments based on the principles of collegiality to build a learning community. 


\subsection{Lesson Study}

Lesson Study as a training model of educators' profession through sustainable and collaborative learning assessments is based on the principles of collegiality which is mutual help in learning to establish a learning community. Lesson Study comes from Japan (from the word: jugyokenkyu) which refers to a systematic process used by Japanese teachers to test the effectiveness of their teaching in order to improve learning outcomes (Garfield, 2006). Systematic process which is referred is a collaborative working of teachers to cyclically and continuously develop lesson plans and equipment, do observation, reflection and revision of lesson plans so that it may create critical thinking as well (Anwar \& Iramawaty, 2015). According to Lewis (2002) Lesson Study is actually short and simple, that is, if a teacher wants to improve learning, one of the most obvious ways is to collaborate with other teachers to design, observe and reflect on the undertaken learning.

When we look at the definition of Lesson Study, we find seven key words, namely professional training, assessment of learning, collaborative, sustainable, collegiality, mutual learning, and learning community. Lesson Study aims to conduct sustainable training of educator profession in order to continuously increase the professionalism of educators. How to train the educators' professionalism? That is through a continuous and collaborative assessment of learning.

Assessment of learning should be done regularly, e.g. once a week or once every two weeks because building a learning community is to build a culture that facilitates members to do mutual learning, mutual correction, mutual respect, mutual trust, and mutual restraint of the ego. Building a culture is not a moment, it takes a long time. Time to build a culture of learning communities has no limit. With regard to learning, no study is perfect, there is always a gap to fix it, so that, learning should be assessed continuously so it can be better in the future (Nani \& Yaya, 2015). Assessment of learning is intended to seek solutions of the learning problems in order to increase the quality of learning. The object of learning assessment can include: teaching materials, method / strategy / learning approach, students' worksheet, instructional media, classroom setting, and assessment. Why learning assessment conducted in collaboration? Because more input of improvements will improve the quality of learning itself. We believe that our instructional preparation has been good, but when it gets input from others there are still things that can improve the quality of instructional preparation.

The principles of collegiality and mutual learning (learn) are important when using lesson study. In other words, the target audience may not feel superior (feeling the cleverest) or inferior (low self-esteem) but all participants in Lesson Study activities should be intended to learn from each other. Participants who have already known or have more knowledge must be willing to share with other participants who do not understand, otherwise participants who have not understood should be willing to ask the participants who have already understood. Lesson Study resource persons in the forum should act as a facilitator, not an instructor. The facilitator should be able to motivate participants to develop their potency so that the participants can be improved together.

Lesson Study is bottom -up because the training material is based on the problem faced by the educators which is then assessed collaboratively and sustainably. Lesson Study is conducted in three stages, the first stage is Plan (plan), the second stage is Do (implement), and the third stage is See (reflects) which are done sustainably. In other words Lesson Study is a way of improving the quality of education that never ends (continuous improvement). The cycle of Lesson Study is as follows: 


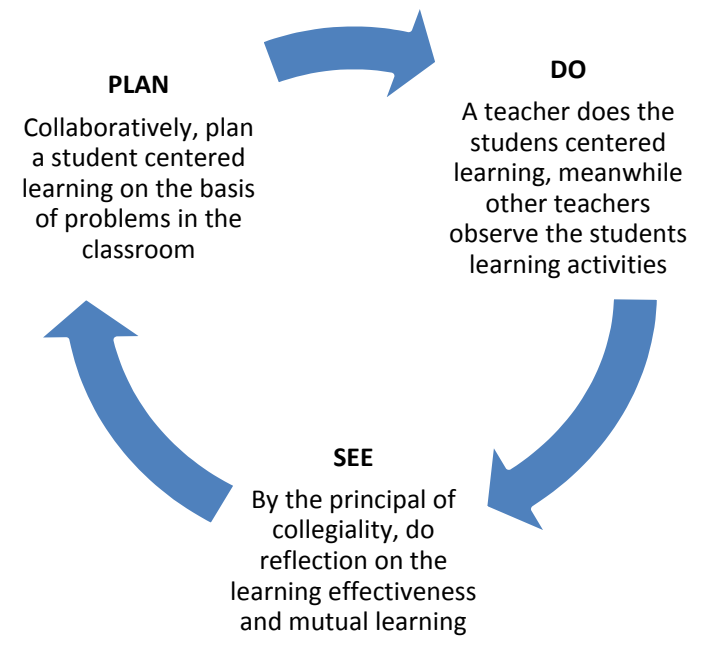

Figure 1. The cycle of learning assessment in lesson study

\section{Method}

This study aims to produce a model of educators' professional training special for remote areas through the implementation of integrative thematic -based lesson study. This research is qualitative description, thus the research design of this study is R \& D (Research and Development) using the version of Borg and Gall (1989, p. 624) and Anwar and Husnia (2016) with the flow as follows:

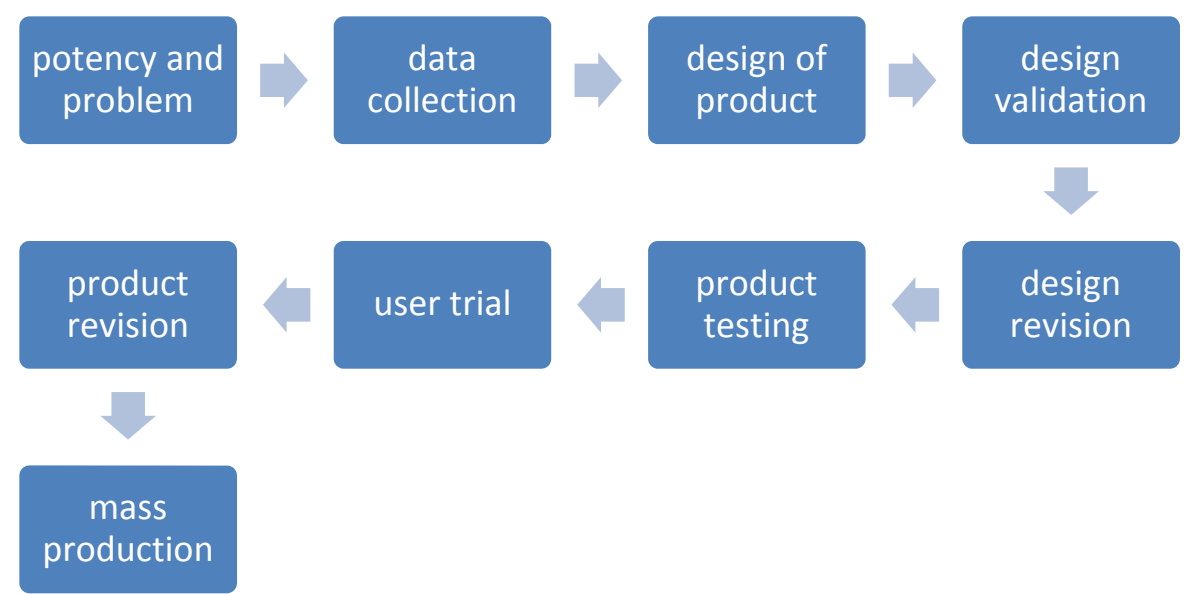

Figure 2. The research design

The second step of this study began from user trial to the revision of the product because the first step of this study has generated a hypothetic model. The stages of the research design that have been done or will be implemented are as follows: (a) Determining the potency and problems in developing the model of educators' professional training special for remote areas requires survey of the research locations, in this case are schools on the Bawean Island, Gresik. Further, seeking data on weather forecasts and the possibility of shipping from Gresik to Bawean Island; (b) Collecting required data to develop the model, namely the school data, teacher data, data of teachers' ability to assemble learning plan, data of teachers' capability in the implementation of learning and teacher data in preparing learning evaluation tools; (C) Developing a design of educators' professional training model special for remote areas; (D) Designing an educators' professional model special for remote areas and then it is validated by experts to give inputs; (E) Revising the design to be a model which is ready to be tested in the field; (F) Testing the design to school which become the subjects of the research; $(\mathrm{G})$ In the process of testing will certainly encounter some problems that may not be appropriate with the model developed, thus it requires revision resulting hypothetical model; $(\mathrm{H})$ Doing trial and further the product is 
applied in real conditions for a wider scope. In this stage, experimental method is used; (I) after testing the model, it is still possible to do revision of the product, and then it will be a model which is ready to be disseminated.

\subsection{Research Subjects}

In this study, the subjects are math teachers in MTs Islamiyah and MA Mambaul Falah in Bawean Island Sangkapura, Gresik regency.

\subsection{Data and Research Instruments}

In this study, the data and instruments needed are as follows: school, teacher, teachers' ability to prepare learning equipment, and teachers' capability in the implementation of learning.

\section{Results}

In the research of developing an educators' professional training model special for remote areas through the implementation of lesson study needs a special strategy that is different from the research of educators' professional training model for areas which are not included in remote area. There are many factors which become the basis to construct the development strategy; this is due to the condition of teachers in remote areas which is very different from other regions. Inaccessibility of public facilities, means of access to education and the shortage of human resources are some interesting factors and should be considered by the researcher to be analyzed.

The required data in formulating the strategy includes general data (primary) and special (secondary). General data is the data that can describe the general condition of the school where teacher carries out daily activities in the educational process. Meanwhile, special data is the data that can describe some of competences owned by educators (teacher). General data includes school data and teacher data, while special data includes the data of teachers' capability in developing learning tools, teacher data in preparing evaluation tool, data of teachers' capability in the implementation of learning and teacher data which describes their professional capability. Professional capability is the ability of a teacher in mastering the material which is proper with the level of education unit where they teach.

The above data are considered to be able to describe two abilities or competencies that must be owned by a professional teacher, namely pedagogic and professional competences. Actually, to be a professional educator (teacher) needs not only those two competences but it needs two more competences; social competence and personality competence. But this study focuses only on pedagogical and professional competences because other two competences will grow automatically if lesson study is implemented as a basis of educators' professional development in this study.

Based on the data required above the researcher prepares research instrument that can be used as a tool to collect these data. The instrument of the study includes school data collection instrument, teacher data collection instrument, instrument of the ability assessment in constructing learning tool, assessment instrument of the ability in the implementation of learning, assessment instrument of constructing instructional evaluation tool and assessment instrument of professional competence in the form of mathematical descriptive questions.

The method of school data collection, teacher data uses direct observation and interviews with the principal. The data collection of teachers' ability to prepare lesson plan is done by observing their syllabi and lesson plans then the team of researchers provides an assessment in accordance with the instrument. For the data collection method of teachers' ability in the implementation of learning, the researcher's team directly observes the learning activities in each teacher's classroom which is assessed. While the data collection method of professional competence uses a written test consisting of test for primary school teachers and test for MTs teachers which each of the tests consists of 6 numbers of questions.

\section{Disscussion}

Based on the analysis of school data, it can be concluded that; (A) The implementation of the educators' professional training in Bawean island cannot be conducted outside Bawean island because it is constrained by the expensiveness of transportation cost, so the implementation of training should be done at the school; (B) Based on the analysis of few number of human resources, then to improve the pedagogic ability cannot be done individually and thus it requires a collaboration among teachers; (C) Concerning the teachers' education qualifications which are more inappropriate with the subjects they teach, then they need assistance by experts of education. In addition to the requirement of increasing the pedagogic competence, the improvement of professional competence is also needed which is in the form of strengthening mathematical material in accordance with their level of education units. To facilitate the companion in carrying out the training, 
collaboration among teachers is needed, so that teachers with appropriate education qualification can provide input to teachers who have inappropriate educational qualification.

Based on the analysis of teachers data, it can be concluded that; (A) A long experience of teaching is possible for the teachers to enable them to be able to develop themselves in improving the quality of learning in their classroom, but because they have not been trained, then their knowledge about the development of education is low. Whereas education is always evolving in terms of educational paradigm, curriculum (latest curriculum in 2013), IT-based learning media, learning methods and preparation of learning tools; (B) Therefore, based on training experience that they never joined, thus it requires training related to pedagogic competence, namely 2013 curriculum and learning innovation socializations. Based on the educational qualifications which do not match, then strengthening the elementary and junior high math material is necessarily done, it is associated with the professional competence. Besides, discussion among teachers in preparing teaching materials is also required.

Based on the data analysis of teachers' capability in developing learning tool, it can be concluded that; (A) pedagogic training is needed in this case is training in: Developing syllabus and lesson plan, developing both contextual and IT-based media since this junior high school (MTs) has a lab. Computers that can be used, developing worksheets that correspond to the lesson plan, developing teaching materials that attract students, developing learning evaluation tools (constructing drafts of questions, questions, answer key and scoring guidelines); (B) The above-mentioned pedagogical abilities need assistance in the arranging so that not only the theory but a workshop should be directly conducted and it is applied to the first semester of school year 2014/2015. The construction is conducted collaboratively among teachers.

Based on the results of data analysis of teachers' ability to prepare learning evaluation tools, it can be concluded that; (A) Due to the low teachers' ability in preparing the evaluation tools, then it is needed to conduct pedagogic training in preparing complete evaluation tools that include: types of assessment, compiling a draft of questions, preparing assessment rubric, composing questions, giving answer keys and guidelines for scoring; (B)Those steps are done collaboratively and continuously within the learning process.

Based on the analysis of teachers' ability data in the implementation of the above learning, it can be concluded that; (A) pedagogic training is required in term of classroom management, strategies and learning methods oriented toward student centered learning; (B) In order to every teacher is able to know their own shortcomings in the implementation of learning in classroom and deficiencies in preparing lesson plans, it is necessary to reflect on the implementation of collaborative learning after learning is done.

Based on the analysis of teachers' professional competence data above, it can be concluded that; (A) A training of professional competence in the form of strengthening the mathematical material which they do not master well is needed. The materials which are less mastered by the teacher of MTs Mambaul Falah are materials of matrix algebra, trigonometry and geometry. Meanwhile, the materials which are less mastered by the teacher of SDNU Raudhatus Sibyan are algebra, set, mathematical modeling and geometry materials; (B) In addition, teacher can do sustainable discussion with other teacher about material that they find any difficult when they are talking in formulating learning tool, so that the presence of a learning community among teachers is needed.

Based on the above conclusion of data analysis, it is actually hard enough to carry out the training to teachers in this remote island, this is due to their low pedagogic and professional ability (Anwar: 2016; Gustine, 2013). There are a lot of abilities that they do not master well. The main factors are the geographical conditions, inadequate public facilities and their educational qualifications are not in accordance with the subjects they teach The implementation of the training to teachers on the island of Bawean is not possible if accompaniment is done continuously, but if they are only treated with training, it will most likely not be implemented in schools, the training will only become a knowledge that will gradually disappear.

Thus we need a training model of educators' profession which is possible to be carried out directly and continuously within classroom learning process and not merely a temporary training. An educator training model which is proper with the above conditions is Lesson Study.

Lesson Study is an educators' professional training model through collaborative and continuous learning assessments based on the principle of collegiality that is mutual help to establish a learning community. Lesson Study comes from Japan (from word: jugyokenkyu), which is a systematic process that is used by Japanese teachers to test the effectiveness of teaching in order to improve learning outcomes (Garfield, 2006; Murtiani et al., 2012). Archer et al. (2013) asserts that lesson study provides opportunities for a teacher to get out of his comfort zone by which he always considers himself able to manage class independently. Systematic process which is referred is teachers collaboratively work to develop lesson plans and learning tools, do observation, 
reflection and revision of lesson plans cyclically and continuously. Lesson Study was started to be developed in 3 State Universities of Indonesia in 1998, they are UPI (Universitas Pendidikan Indonesia) in Bandung, UNY (Yogyakarta State University) in Yogyakarta and UM (University of Malang) in Malang in cooperation with JICA (Japan International Cooperation Agency). In addition, starting in 2001, Lesson Study began to be developed in schools around those Universities' area to enhance the learning of Mathematics and Science. Furthermore, at this time, Lesson Study is developed continuously and evenly distributed in various regions in Indonesia through a grant -funded program by Indonesian government.

According to Lewis (2002), idea contained in the Lesson Study is actually short and simple, that is, if a teacher wants to improve learning, one of the most obvious ways is to collaborate with other teachers to design, observe and reflect on the undertaken learning. Thus it is appropriate with the conditions that exist in the schools in the island of Bawean .

The principles of collegiality and mutual learning (learn) are applied collaboratively when Lesson Study is conducted. In other words, the participant of the Lesson Study may not feel superior (feel cleverest) or inferior (low self-esteem), but all participants Lesson Study activities should be intended to learn from each other. Participants who have already known or have more knowledge must be willing to share with the participants who have not understood, otherwise participants who have not understood should be willing to ask the participants who have understood. The resource person of Lesson Study in the forum should act as a facilitator, not an instructor. The facilitator should be able to motivate participants to develop their potency, so that the participants can be better together.

In Lesson Study, there are 3 stages consisting of plan, do and see (Anwar: 2015). Plan is a teacher collaborative construct a learning tool together that will be used to teach in a particular class. The tools composed are syllabus, lesson plans, and worksheets, teaching materials, media and assessment tools. The assembly of learning tool is done jointly in order to the resulted learning tool is resulted from the discussion which is better than learning toot that is developed individually. In the process of constructing learning tool, one with the other teachers is able to provide input so a learning community in collegiality can be created. It would be appropriate to be applied in schools in Bawean Island since not all of the teachers there have appropriate qualifications with the subject they teach. Plan activity can be done one week before the learning process in the classroom or (do).

Do is an activity to implement a learning tool that has been compiled. In implementing a learning tool in the classroom, one person acts as a teacher who is called as a model teacher and other teachers act as observers. The observations are done in the classroom to observe activities of students in the classroom with the aim to produce findings related to the learning process in the classroom that can be used to repair the next learning.

See or reflection is an activity to analyze and evaluate learning activity that has been performed. See activity starts from the model teacher delivers the thing that is felt when he becomes a model teacher. Then each observer conveys the findings in classroom, and then it is discussed together for the next learning improvement. One stage in Lesson Study (plan, do and see) can be called as one cycle. Thus it can be developed an educators' professional training model special for remote areas, after it is validated by the expert, further it is revised and tested, next it is revised again, and then it will produce a model as seen below: 


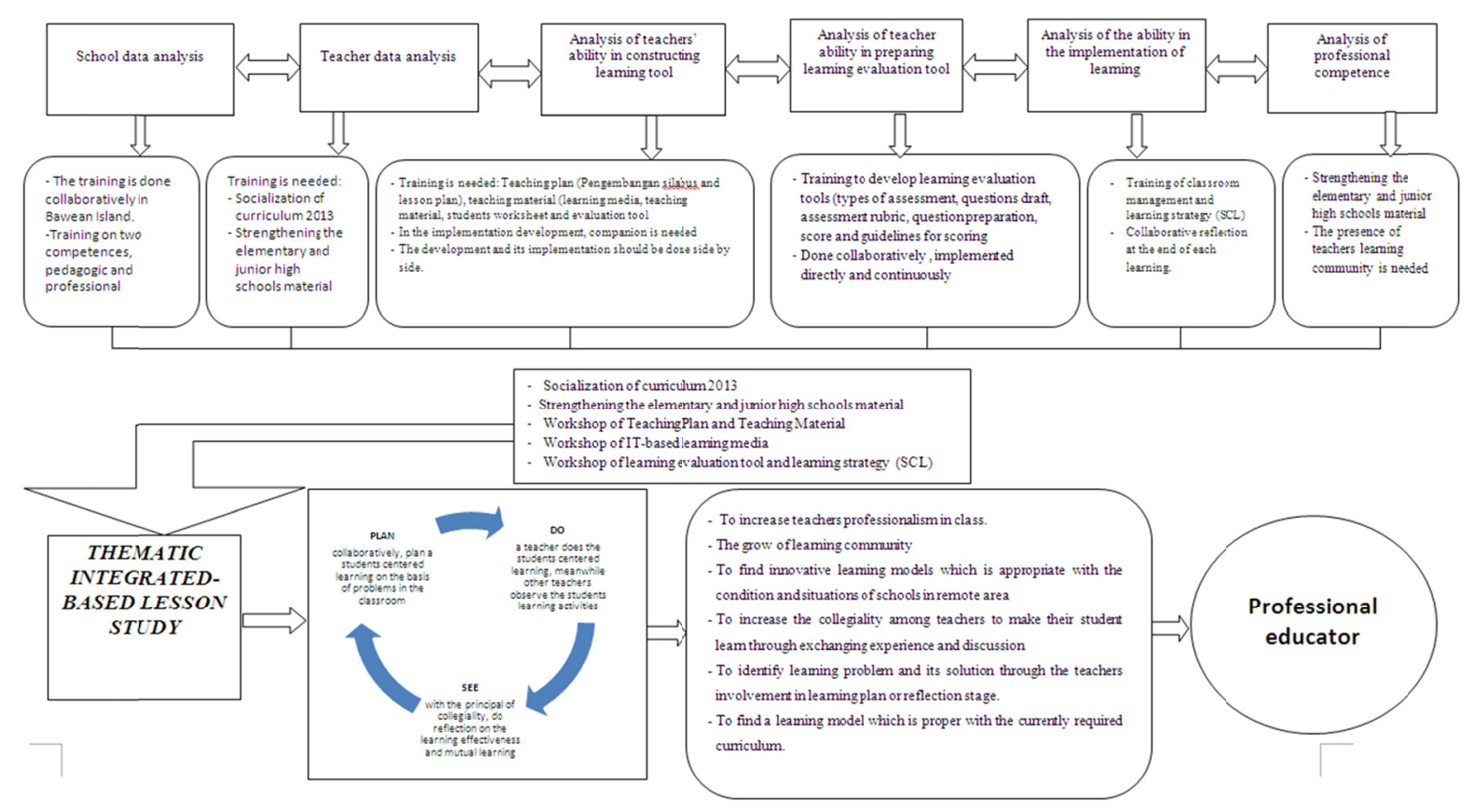

Diagram 1. The educators' professional training special for remote area

\section{Conclusion}

1) The process of educator professional model development in remote is as follows: (a) Analysis of the potency and problems of education in Bawean; (b) Data collection, which consists of: school data, teacher data, teachers' ability in developing learning tools, the ability of teachers in preparing learning evaluation tool, the ability of teachers in the implementation of learning, professional competence; (b) Design of the model; (c) Validation of the model; (d) Revision of the design; (e) model testing; (f) model revision.

2) The hypothetical model of the educators' professional model special for remote areas by implementing integrative thematic -based lesson study is as indicated in diagram 1, with the implementation steps are as follows: (a) analysis of school data that can generate the following conclusions: The development is held collaboratively in Bawean, training is done on two competences, namely pedagogic and professional competences; (b) Analysis of teacher data that can generate the following conclusions: socialization curriculum 2013 is needed, the strengthening of primary and junior secondary material is required; (c) data analysis of teachers' ability to prepare learning tool that can generate the following conclusions: It requires training on: Teaching plan (development of syllabi and lesson plans), teaching materials ( teaching media, teaching materials, worksheets and evaluation tools, the development of its implementation needs an assistance, the development and the implementation are done collaboratively; (d) Analysis of the teachers' ability in preparing the learning evaluation that can produce the following conclusions: The training in developing a learning evaluation tool(types of assessment, questions draft, assessment rubric, question preparation, score and scoring guidelines), is conducted collaboratively, implemented directly and continuously; (e) Analysis of the teachers ability in implementing the learning that can produce the following conclusions: training of classroom management, strategy and methods of learning (SCL), collaborative reflection at the end of learning; (f) Analysis of teachers professional competence that generate the following conclusions: the strengthening of the elementary and junior high schools materials, the presence of a learning community among teachers is needed; (g) curriculum 2013 socialization; (h) Reinforcement of elementary and junior high schools materials; (i) Workshop on teaching plan and teaching materials; (j) Workshop of IT-based learning media; (k) Workshop on evaluation tool and learning Strategy SCL); (1) 4 cycles implementation of lesson study.

\section{References}

Anwar, K. (2015). A Constructive Teaching Model in Learning Research Concept for English Language Teaching Students. International Education Studies, 8(5), 62. https://doi.org/10.5539/ies.v8n5p62

Anwar, K., \& Husniah, R. (2016). Evaluating Integrated Task Based Activities and Computer Assisted Language Learning (CALL). English Language Teaching, 9(4), 119. https://doi.org/10.5539/elt.v9n4p119 
Anwar, K., \& Iramawaty, L. (2015). Writing Factual Report: A Potential Way To Enhance Student's Critical Thinking Ability. JINoP (Jurnal Inovasi Pembelajaran), 1(2), 141-149. https://doi.org/10.22219/jinop.v1i2.2568

Archer R., Pope S., Onion A., \& Wake G. (2013). Working group report: lesson study in research and CPD in mathematics education. Proceedings of the British Society for Research into Learning Mathematics, 33(2).

Direktorat Pembelajaran dan Kemahasiswaan. (2011). Pedoman Penulisan Makalah Lesson Study Untuk Seminar Exchange Experience. Dirjen Dikti, Kementrian Pendidikan Nasional, Jakarta.

Gustine, G. G. (2013). Designing and implementing a critical literacy-based approach in an Indonesian EFL secondary school. International Journal of Indonesian Studies, 1 .

Ibrohim. (2011), Lesson Study untuk Meningkatkan Kompetensi Pendidik, Kualitas Pembelajaran dan Perkembangannya Di Indonesia. Makalah disajikan dalam Seminar Nasional Lesson Study di UNTAD Palu, 28 Oktober 2011.

Jeane, C. (2007). Lesson Study As A Form of Professional Development for Teaching and Learning Mathematics (A Dissertation, New Mexico State University).

Karim, A. (n.d.). Implementation of Lesson Study for Improving the Quality of Mathematics Instruction in Malang. Faculty of Mathematics and Science, State University of Malang.

Lewis, C. C. (2002). Lesson Study: A Handbook of Teacher-led Instructional Change. Philadelphia, PA: Research for Better Schools, Inc.

Murtiani, Fauzan, A., \& Wulan, R. (2012). Penerapan Pendekatan Contextual Teaching and Learning (CTL) Berbasis Lesson Study dalam Meningkatkan Kualitas Pembelajaran Fisika di SMP Negeri Kota Padang. Jurnal Penelitian Pembelajaran Fisika, 1, 1-21

Nani, K., L., \& Yaya S., K. (2015). The Effectiveness of ICT-assisted Project- Based Learning in Enhancing Students' Statistical Communication Ability. International Journal of Education and Research, 3(8).

\section{Copyrights}

Copyright for this article is retained by the author(s), with first publication rights granted to the journal.

This is an open-access article distributed under the terms and conditions of the Creative Commons Attribution license (http://creativecommons.org/licenses/by/4.0/). 